Discourse and Communication for Sustainable Education, vol. 11, no. 2, pp. 45-64, 2020

\title{
Supporting a Sustainable Way of Life-Long Learning in the Frame of Challenge-Based Learning
}

\author{
Maria Hercz \\ Eötvös Loránd University, Budapest, Hungary \\ Ferenc Pozsonyi \\ Eötvös Loránd University, Doctoral School of Education, Budapest, Hungary \\ Nikolett Flick-Takács \\ Szeged University, Doctoral School of Education, Szeged, Hungary
}

\begin{abstract}
The education of children in the Age of Knowledge is a challenge for educators all over the world since it is questionable how we can educate learners to become responsible citizens in different areas. Finding a suitable methodology is a highlighted goal of presentday educational researches. The intention of our work is to contribute to this dispute with a research investigating the challenge-based-learning-adapting European UKids programme designed for eight-to-eleven-year-old learners. This intention aims to support their education for sustainability and to develop social entrepreneurship and life-long learning. The program is a professional collaboration among university teachers, primary school teacher candidates and learners, thus the research manages this triplet as a complex entity.
\end{abstract}

The scientific paradigm and structure of present paper is rather nonconventional since, instead of presenting an empiric research, it interprets some peculiarities of many research units with the help of mixed methodology. Four research phases had been distinguished, the first three of these applied quantitative research methods.

Results suggest that the learners are somewhat satisfied with their schooling and learning circumstances. Although they prefer constructive learning strategies, teacherdirected methods are still more popular among the responses which means that the non-traditional work forms are rather unfamiliar to them. The programme affected their skills and competences in a positive way. An age-specific (socio) psychological dichotomy was detected; however, the framework of the UKids programme was able to handle it. Both challenge-based learning and the UKids programme turned out to be suitable for educating and developing children in a complex way, and they are able to trigger innovation in teacher-training.

Key words: entrepreneurship education, challenge-based learning, life-long learning, indirect education for young learners, teacher training. 


\section{Introduction}

The effective teaching-learning process is a core issue of present-day pedagogy. The novelties of the late- $20^{\text {th }}$ and the early- $21^{\text {st }}$ century have been transforming our society and labour market radically, and in the continuously changing globalized world it is a must to educate children to be prepared for life-long learning and sustainabilitywise thinking, and to become responsible citizens.

The aim of this study is to introduce how this mission could be accomplished. The Hungarian adaptation of the Erasmus+ KA201 UKids programme by Eötvös Loránd University, based on the European Youth Start project, is taken as an example and also as a research area. The execution of the programme is the result of many collaborative professionals; therefore all these agents are investigated.

First, those international research projects are summarized because they are relevant to the question of understanding the current learners' generation in the educational system, to the preferred values in their education, and to the possible alternative ways of teaching and learning. The methodological section describes the research paradigms, the samples and applied devices in detail. Since this paper interprets the last two years of programme-execution, its findings are introduced in chronological order; however, there is a dedicated section to summarize the results.

\section{Educational Issues after the Millennium: The Importance of Life-Long Learning}

Educational theory always questions who and how should teach who for what. To form a basis for our study about the importance of life-long learning and its supporting possibilities, it is reasonable to review the platitude-like evidence, trying to answer these questions in the context of contemporary schooling

Who is taught? Today's children are generally considered as members of an agespecific generation. Fedosejeva et al. (2018) claim that the so-called Generation Z acquire knowledge and skills through information and communications technology (ICT). Besides these phenomena, the connection between children's needs and schooling should also be considered (Johnson et al., 2009; Claxtron, 2013). In one of his lectures Claxtron (2017) likens learners to psychologically disabled "wheelchair-users" who are dragged by their teachers lesson by lesson, therefore the learners only task is to adapt to their passive role. When the school bell rings, learners rise from their wheelchairs and continue their active and dynamic lives. This caricature attracts the attention to the inevitable one-century-old demand for student-centred teaching (reform movements). Still, in the $21^{\text {st }}$ century it is essential to be aware that children's development is a multifactorial process: the operation of learning groups is highly influenced by the inconstant interaction between learners' individual differences and age-specific peculiarities (McAdams \& Palsh, 2006). Consequently, school-goers cannot be handled as members of a solid group, and similarly, theorists of children development do not fully agree about whether the development of individuals is periodic (Erikson, 1963; Feldman, 1999; Piaget, 1983); or continuous (Bandura, 1986; Bruner, 1996); or if it is affected by other factors (Bronfenbrenner, 1979).

What should be taught? The changing economy with the rapid transformation of the labour market and the new idols of the emerging professions are well-known research topics. Numerous models have been developed to list the preferred skills in the $21^{\text {st }}$ century (for example, Trilling \& Fadel, 2009; Heasly et al., 2019, 2020; Salìte et al., 2007) here 
our intention is to highlight one set of skills suggested by the World Economic Forum. Instead of the classic pedagogical and psychological approximation, the model conceptualises skills: foundational literacy, competences, and character qualities, but respecting labour market necessities and the need for social involvement. This places life-long learning centrally to serve as a general context for them. The appearance of the character qualities (for example leadership, social and cultural awareness) in the model suggests that continuous personality development should be started in childhood with a focus on conscious ICT usage (WEF, 2016, p. 4). The above mentioned skills could be interpreted in the framework of sustainability (Heasly et al., 2019) and it leads to the issue of implication.

How should they be taught? WEF (2016) suggests social emotional learning as an effective way for teaching and learning skills and competencies; however, there is a lack of a comprehensive theoretical base which could serve as a starting-point for the possible in-practice execution. This goal-oriented attitude proposes curriculum development and in the case of entrepreneurship education a comprehensive model is essential. Systematically speaking, entrepreneurship education could be fitted into the framework of lifelong learning and sustainability (see Figure 1).

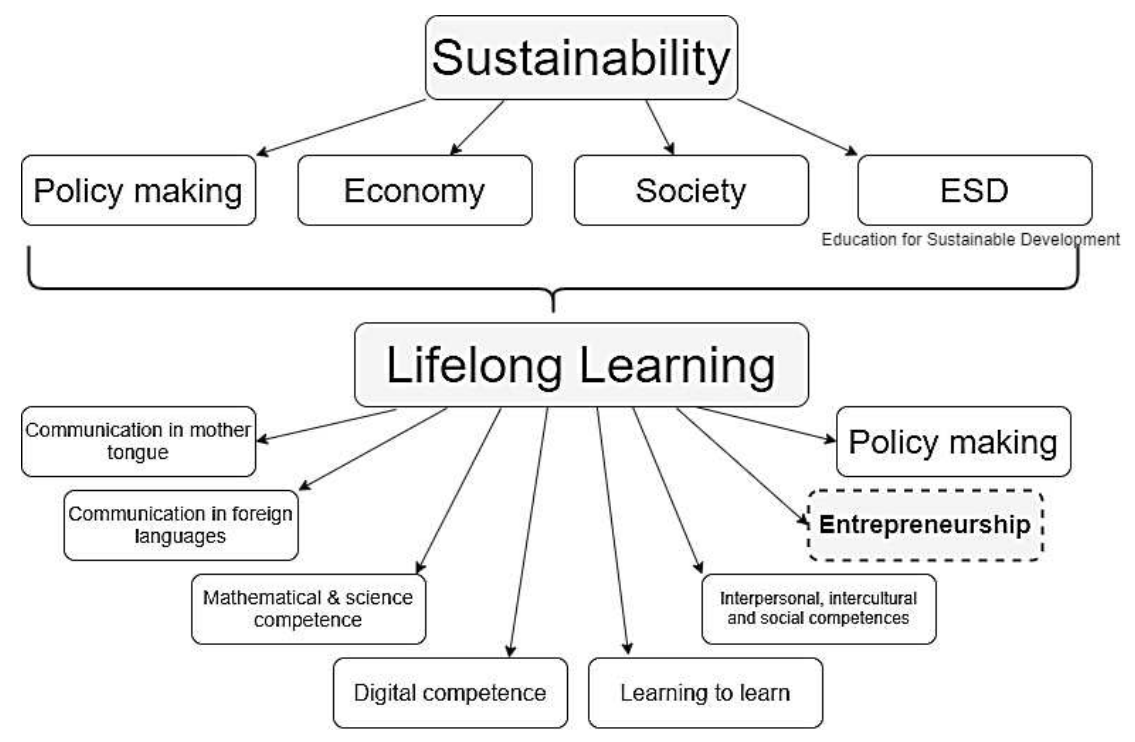

Figure 1. Entrepreneurship in the context of sustainability and life-long learning (Takács, N., 2019 based on UNESCO, 2014; Sahin et al., 2010, p. 547)

Different research results indicate the significance of social and emotional learning which could be implied with the help of games and active learning methods (Samuelsson \& Kaga, 2008, p. 11; Sahin et al., 2010; Ülavere, 2017, p. 131; Slušnienè, 2019, p. 134; Fedosejeva et al., 2018; Heasly et al., 2019). The shift from traditional classroom management to active learning could result in not just transfiguration in teachers' coachlike role (Johnson et al., 2009) but learners' better academic outcomes because of cooperation (Johnson \& Johnson, 1999; Igel \& Urquhart, 2012). "The pendulum seems to swing not only between the internal (focusing on children's abilities) and external (content of teaching) poles, but also along a triangle, set by the internal/psychological, content/ disciplinary and social needs/application points" (Csapó, 2010, p. 12). 
As a natural derivative of the constructive learning theory, problem-based learning appeared on the educational stage in the middle of the $20^{\text {th }}$ century (Boud \& Feletti, 1997), and with its learner-centred concept, a completely different approach to teachers' role, classroom management and assessment was introduced. Surprisingly, it has not met a warm response from educators; however, the later emergence of the information society demands extensive problem solving from today's learners (Walker et al., 2015).

Similarly, a central motive could be detected in the case of challenge-based learning that is exploiting and solving real-world problems. This relatively new movement runs back to the ACOT research which was designed to map learners' wellbeing (Apple, 2008). The learning process consists of management phases, each building on the other: detecting so-called Big Ideas, forming questions, investigating, solving the challenge, and publishing the results. The ancillary effect of applying challenge-based learning is simultaneous knowledge acquisition and skills development (Nichols et al., 2016). Problem-based and challenge-based learning methods are compared in details in Table 1.

Table 1

Comparison of the Properties of Problem-Based and Challenge-Based Learning (Hercz, M. based on Boud, D., \& Feletti, G. I., 1997; Johnson et al., 2009; Walker et al., 2015)

\begin{tabular}{lll}
\hline \multicolumn{1}{c}{ General properties } & Challenge-based learning & Problem-based learning \\
\hline Theoretical basis & constructivist pedagogy & constructivist pedagogy \\
\hline Perspective & future & present \\
\hline Scope & wider & narrower (current task) \\
\hline Focus on & learner & learner \\
\hline Scientific link & interdisciplinary & interdisciplinary \\
\hline \multicolumn{1}{c}{ Didactical properties } & & \\
\hline Focus acquisition & importance of process & importance of result \\
\hline Preferred command by & learner & learner \\
\hline Content of tasks & dynamic & static \\
\hline Selecting tasks & mainly optional & compulsory \\
\hline Nature of tasks & open-ended (multiple results) & close-ended (one or some \\
& results) \\
\hline Nature of information used & searching for new one & using the learnt one \\
\hline Preferred management & individual or group-work & group-work \\
\hline Preferred assessment & self and peer-assessment & self and peer-assessment \\
\hline \multicolumn{1}{c}{ Teacher's properties } & & \\
\hline Role & facilitation & facilitation \\
\hline Effect on learner & compelling & forcing/obligating \\
\hline \multicolumn{1}{c}{ Learner's properties } & & \\
\hline Type of inclusiveness & higher emotional & higher cognitive \\
\hline Task selection & independent & assigned \\
\hline Source of motivation & inner drive & outer pressure \\
\hline Feelings associated & excitement, experience & stress, relief \\
\hline
\end{tabular}


One practical implication of the challenge-based learning is an international Erasmus+ KA201 project, titled "UKids" (UKids, 2018) which applies active learning in order to promote social entrepreneurship development for young learners between the ages of eight and eleven. Researchers, teachers and teacher candidates from six European countries have been developing and adapting a complex programme to help children become active and responsible citizen by empowering them with the most important $21^{\text {st }}$ century competences. The theoretical background of the UKids programme is strongly attached to the so-called TRIO model, an interlock of three implementing areas: entrepreneurial education, entrepreneurial culture, and entrepreneurial civic education (Lindner, 2019, p. 6; Hercz, 2019).

At this point, it is essential to define the nomenclature thoroughly. In this article a broader concept of "entrepreneurial education" is used. This denotes the foundation of economic education and extends to contain general personality development, including the development of various personal moral values (initiative, courage, creativity) and competencies (self-knowledge, self-esteem, thinking, communication, problem-management, cooperation). These values and competences are helpful to individualize, be problemsensitive, dare to think outside the box, etc. (Angyal \& Hercz, 2019, p. 11); moreover, they could form a strong base for life-long learning through alternative, mostly nonformal and informal learning (Sahin et al., 2010).

Since UKids Erasmus+ KA201 is defined as a project, its units, called "challenges" in classroom environments, are referred to as thematic subprojects. In everyday practice, these are realised in different project works or project-oriented works with the help of individual, group, class or beyond-class work. Their topics are the thematic challenges specified in the UKids framework (Lindner, 2018).

\section{Methodology Applied}

\section{Research Paradigm}

A mixed research methodology (Creswell, 2009) was applied in our research. Its usage was reasonable since a specific phenomenon could be investigated more thoroughly with dissimilar approaches; moreover, numerous different questions arose as the UKids project proceeded. From the typological point of view, explanatory and exploiting models were present (Creswell, 2009). Multiphase, more specifically, convergent parallel design was initiated; which means that the research group simultaneously and independently work on quantitative and qualitative data collection and analysis; then the results of the two research methods are summarised and interpreted only in the last phase of the research (Gliner et al., 2017).

The research was conducted in three phases matching school years: the first one in 2017/2018, the second one in 2018/2019, and the third one in 2019/2020. In the first two phases, quantitative methodology with questionnaires was applied; and data analyses were performed with IBM SPSS 25 software.

The third phase applied qualitative methods since documentary analysis made a holistic, unstructured and intuitive interpretation possible (Bowen \& Glenn, 2009). Content analyses were performed on seven primary school teacher candidates' theses with ATLAS.ti 8 software. The teacher candidates were members of the research group, and during the run of UKids, they created and executed thematic projects, and documented 
and analysed these with the help of their consultants. From a methodological point of view, their theses are case studies which used methodological triangulation with the following basis: oral and written interviews, learners' planner booklets, and teacher candidates' lesson plans and observations. The Grounded Theory was applied for the qualitative analysis (Corbin \& Strauss, 2015) in parallel with the research; the open coding was followed by the theoretical coding with the formation of an interpretation framework fulfilled by documents supporting pros and cons.

\section{Process and Characteristics of the Research}

During the Hungarian involvement in the UKids project from 2017 to December 2020, 375 children and 30 primary school teacher candidates took part in who planned, organized and executed the programmes in the first two and a half years. Since the research has not been finished yet, present paper discusses only its already-processed and interpreted data in connection with educating for life-long learning. Four research units were interpreted for this paper; their peculiarities are introduced in Table 2.

Table 2

The Scope of Participants and the Details of Data Collection in the Different Research Phases

\begin{tabular}{|c|c|c|c|}
\hline $\begin{array}{l}\text { First phase (2018) } \\
\text { Children's views on } \\
\text { school }\end{array}$ & $\begin{array}{l}\text { Second phase (2018) } \\
\text { Pilot project }\end{array}$ & $\begin{array}{l}\text { Third phase } \\
\text { (2018/2019) } \\
\text { Children's views on } \\
\text { themselves, their lives } \\
\text { at home and school }\end{array}$ & $\begin{array}{l}\text { Fourth phase } \\
\text { (2018 - Dec 2019) } \\
\text { Teacher candidates' } \\
\text { research records on } \\
\text { UKids thematic projects }\end{array}$ \\
\hline $\begin{array}{l}\text { 9-11-year-old } \\
\text { children }\end{array}$ & $\begin{array}{l}\text { 10-11-year-old } \\
\text { children } \\
1 \text { teacher candidate }\end{array}$ & $\begin{array}{l}\text { 9-11-year-old } \\
\text { children }\end{array}$ & $\begin{array}{l}\text { teacher candidates } \\
\text { (researching in different } \\
\text { institutions) }\end{array}$ \\
\hline $\begin{array}{l}\text { In different regions } \\
\text { of Hungary }\end{array}$ & $\begin{array}{l}\text { At ELTE } \\
\text { Gyertyánffy István } \\
\text { Practicing Primary } \\
\text { School, Budapest }\end{array}$ & $\begin{array}{l}\text { In Grades } 3 \& 4 \\
\text { at ELTE Gyertyánffy } \\
\text { István Practicing } \\
\text { Primary School, } \\
\text { Budapest }\end{array}$ & $\begin{array}{l}\text { At ELTE Practicing } \\
\text { Primary School, Lázár } \\
\text { Ervin Primary School, } \\
\text { a children's home, } \\
\text { in the capital city and } \\
\text { at rural areas }\end{array}$ \\
\hline $\mathrm{N}=1,237$ & $\mathrm{~N}=24$ & $\mathrm{~N}=134$ & $\begin{array}{l}\mathrm{N}=7 \text { teacher candidates } \\
\mathrm{N}=243 \text { children's work } \\
\text { (out of } 375 \text { ) }\end{array}$ \\
\hline $\begin{array}{l}\text { Questionnaire: } \\
\text { Cronbach's } \\
\alpha=0.824,46 \text { items } \\
\text { selected by learning- } \\
\text { related views and } \\
\text { effects }\end{array}$ & $\begin{array}{l}\text { Mixed methodology: } \\
\text { questionnaire, } \\
\text { interview, learners' } \\
\text { planner booklets }\end{array}$ & $\begin{array}{l}\text { Questionnaire: } \\
\text { Cronbach's } \\
\alpha=0.81275 \text { items }\end{array}$ & $\begin{array}{l}\text { Case-study-like theses: } \\
\text { observation, interview, } \\
\text { document analysis of } \\
\text { learners' planner } \\
\text { booklets }\end{array}$ \\
\hline Quota sampling & Complete sample & Complete sample & Complete sample \\
\hline $\begin{array}{l}\text { Online, with assis- } \\
\text { tant teacher, in } \\
\text { classroom }\end{array}$ & Paper-and-pencil & $\begin{array}{l}\text { Paper-and-pencil, } \\
\text { with assistant teacher, } \\
\text { in classroom }\end{array}$ & $\begin{array}{l}\text { Paper-and-pencil, with } \\
\text { assistant teacher, in } \\
\text { classroom }\end{array}$ \\
\hline
\end{tabular}


In the first phase, a nationwide children's voice research with online data survey in two thirty-minute-long sessions was conducted. Originally, its questionnaire had contained 174 items of which 46 items were extracted using thematic categories related to respondents' learning-related views. It is vital to take the content and the environmental peculiarities of the sample into consideration in order to be able to detect connections in our large sample research. As for the gender, the sample is balanced: $53 \%$ male, $46 \%$ female, and $1 \%$ no answer. Table 3 displays the distribution of the sample by living place and the highest qualification of respondents' parents if the children were able to answer that question $(65 \%)$.

Table 3

Respondents' Living Place and Their Parents' Highest Qualification (in percentage)

\begin{tabular}{lccccc}
\hline & $\begin{array}{c}\text { Primary } \\
\text { school }\end{array}$ & $\begin{array}{c}\text { Vocational } \\
\text { training }\end{array}$ & $\begin{array}{c}\text { Matura } \\
\text { examination }\end{array}$ & Degree & $\begin{array}{c}\text { Total living } \\
\text { places* }\end{array}$ \\
\hline Village & 69 & 28 & 39 & 29 & 32 \\
\hline Town & 21 & 43 & 25 & 23 & 32 \\
\hline City & 10 & 15 & 13 & 13 & 14 \\
\hline Capital & 0 & 14 & 23 & 35 & 22 \\
\hline Total & 100 & 100 & 100 & 100 & 100 \\
\hline Total sample & 3.5 & 45 & 17.5 & 34 & 100 \\
\hline
\end{tabular}

$\mathrm{N} \mathrm{school}_{\text {(total) }}=1,237$ [N school $\left._{\text {(missing) }}=429 ; \mathrm{N} \mathrm{school}_{\text {(valid) }}=808\right]$.

Asterisk indicates the case of having the qualification by one of the parents.

The second phase accomplished the pilot project with the intention of developing another questionnaire for later usage. After exploiting the relevant questions of the before-mentioned nationwide survey, we added further items using some theoretical background. After trials and corrections, the overall and thematic-group-related reliability of the questionnaire was higher than Cronbach's $\alpha=0.8$ thus it was considered reliable and was used in the third phase.

In the quantitative part we assumed that learners participating in the nationwide survey:

1) have a reasonably positive attitude towards their schools, therefore they are enthusiastic school-goers,

2) are able to assess their learning circumstances and conditions properly; however, it is also assumed that due to their age-specific peculiarities these conditions and the possibility of non-formal learning at school is also positive for them,

3) have attitudes towards learning which correlate to learners' socioeconomic status and the size of their place of living,

4) have a more positive vision on non-traditional learning work forms, and

5) prefer learning methods encouraging active learning.

In the qualitative part of our research we focused on the following problematic areas:

1) The challenge-based-learning-founded UKids supports the development of self-directed learning and responsible social and civic behaviour which are inseparable from life-long learning and education for sustainability.

2) It is assumed that UKids project should be appropriate for learners' age-specific personal characteristics, at the same time these yet-unknown characteristics are to be mapped. 


\section{Children's Voice Research on Learning and School}

Findings of present research are presented in chronological and logical order as depicted in Table 2. This chapter introduces the quantitative research conducted in the first phase.

\section{Learners' Attitudes towards Learning and Attending School}

The investigation of this relationship was highly important, thus different questions of the questionnaire dealt with it. Besides general inquiry, learners were asked to evaluate different items. We used these variables to create new ones with the help of factor analysis with principal components method, using varimax rotation $(\mathrm{KMO}=0.85 ; \mathrm{SG}=0.00)$. Then other new variables were created using items related to different factors: (1) personal circumstances of the school, for example teachers, helpers, relation to them, their helpfulness, (2) tangible circumstances of the school, for example equipment, devices, (3) nonformal opportunities and functional spaces of the school, for example out-of-classroom areas for communication, playing, sport activities, and workshops. The average of learners' attitude towards school is lower than we expected, while there is a paramount difference among respondents $(\sigma=0.9)$. Sixty-five percent of the responding Grade-4 learners like attending school, and twenty percent really like doing so. This could be considered as a positive result; however, there are considerably neutral and some dismissive answers, too. Class teachers were highly appreciated similarly to the tangible circumstances, but the satisfaction with the areas ensured by schools are lower ranked (see Table 4).

Table 4

Some Statistical Features of the Children's Relation to School

\begin{tabular}{|c|c|c|c|c|c|c|c|c|c|}
\hline \multirow{2}{*}{ Mean } & \multirow{2}{*}{ St. dev } & \multirow{2}{*}{ Item } & \multicolumn{5}{|c|}{ Frequencies of responses $(\%)$} & \multirow{2}{*}{ Sum. } & \multirow{2}{*}{$\mathrm{N}$} \\
\hline & & & 1 & 2 & 3 & 4 & 5 & & \\
\hline 3.77 & .907 & Like to go to school & 1.8 & 5.8 & 27.1 & 44.3 & 21.1 & 100 & 1,229 \\
\hline & & Factors & & & & & & & \\
\hline 4.44 & .615 & Personal circumstances & .2 & 1.7 & 5.1 & 27 & 65.9 & 100 & 1,231 \\
\hline 4.16 & .587 & Tangible circumstances & .1 & .2 & 7.3 & 22.9 & 69.5 & 100 & 1,215 \\
\hline 4.01 & .687 & $\begin{array}{l}\text { Non-formal learning } \\
\text { opportunities and func- } \\
\text { tional spaces }\end{array}$ & .3 & 3.2 & 7.9 & 37.2 & 51.3 & 100 & 1,218 \\
\hline
\end{tabular}

Items evaluated on a scale of five.

Adding demographic background factors to ANOVA and Tukey's-b tests, notable differences were detected: because of the dissimilar sample size of the subsamples, learners who have highly-qualified parents assessed more critically in the case of personal learning circumstances (difference 0.5) and non-formal and out-of-class learning (difference 0.6). Other background factors do not signal any differences.

\section{Learners' Attitudes towards Different Work Forms}

Direct questions (for instance "Which work forms are you fruitful in?") and indirect statements were used to map learners' attitudes, and then variables were created for 
further calculations. Considering the peculiarities of learners' age, we had assumed that group work could be the most popular but the opposite turned out to be true. As it is stipulated in Figure 2 and Table 5, frontal and pair work, the two frontally-organized and homogenous work forms in practice tend to be the most popular ones, possibly because they are commonly and/or exclusively used. From a wider angle and on the disputed theoretical basis it could be stated that education for sustainability, entrepreneurship and self-regulated learning for life-long learning requires ability and openness for individual and team work therefore their introduction and endearing is vital.

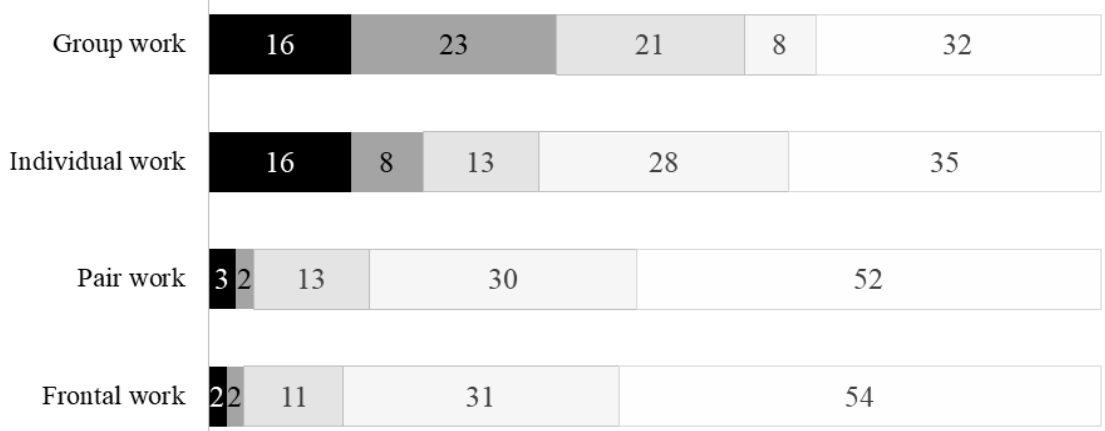

$\mathrm{N}=1,229$; Items evaluated on a scale of five, black indicated the lowest rank, white the highest one.

Figure 2. Popularity of the work forms: Frequency distribution (in percentage)

Table 5

Means of Different Work Forms

\begin{tabular}{ccccc}
\hline & Frontal work & Pair work & Individual work & Group work \\
\hline Mean & 4.4 & 4.2 & 3.6 & 3.2 \\
\hline St. dev & .878 & .995 & 1.427 & 1.487 \\
\hline
\end{tabular}

$\mathrm{N}=1,229$; evaluated on a scale of five.

The relationship to different work forms applied on a daily basis was also investigated. Calculating correlation coefficient $(\mathrm{p}<0.01)$, correlations were detected between three work forms and liking for school: those who like individual work are also fond of attending school $(\mathrm{r}=0.489)$; a similar response happens in the case of frontal work; while pair-work shows a low coefficient $(r=0.214)$.

Using the background factors, by the respondents' living place there was a significant difference in the case of individual work (analysis of variance, significance $p<0.05$ ): it is more popular for those who live in larger living places (3.8) than in smaller settlements (3.4). By parents' highest qualification, frontal work (difference 0.4) and individual work (difference 0.8) are the less popular for those learners whose parents have lower schooling. Group work is the most popular form of work; a difference was detected in the case of highly-qualified parents: 0.6 on a scale of five. It raises a thoughtful issue about why the well-educated parents' children are dismissive of group work. 


\section{The Intention of Learning}

During the process of educating for life-long learning, an emphasised aim is to internalize learning motivation; in other words, to recall the inborn motivation for acquisition. Eight items were about the function of learning. With the use of cluster analysis (see Figure 3), two groups of the outer incitement could be distinguished in outer motivators: (1) ones linked to the educational system (good mark for further education; compulsoriness, the strongest item with a derived mean of 4.6); (2) learners' personal circumstances (derived mean of 4.4), more precisely suiting parental expectations (4.5) and recognition by peers (4.3) and the demand not to lag behind the peers. Selfregulation ("I would learn if marks were not given.") is well-separated: $43 \%$ of the respondents fully agree with this statement and only $20 \%$ of them would stop learning without getting evaluation. This result suggests that in this age-group, there are enthusiastic children with a thirst for knowledge. Another branch of the dendogram displays learning for teacher-student relationship and getting encouragement through assessment for learning; these two items show almost identical mean (3.9) and deviation (1.2).

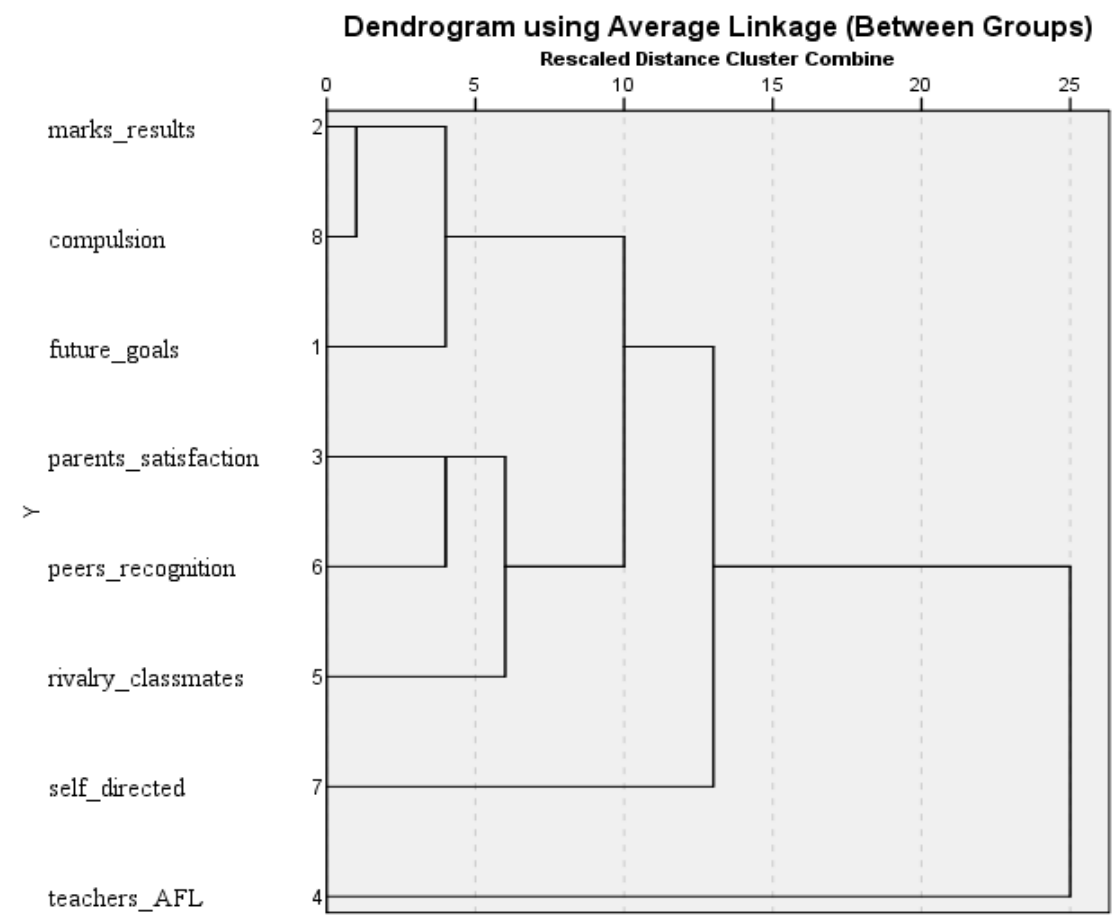

Note: Statements with negative content were converted and interpreted as reversed (e.g. compulsory learning at school).

Figure 3. Learners' motives for learning $(\mathrm{N}=1,236)$

Background factors confirm a trend again: those learners, whose parents are not well-educated, exhibit habits of thinking that is different from the others in many cases. They are far more likely to believe in the motivation by grades and the compulsoriness. Moreover, their learning is the least motivated by further education (significance of -0.5 ), parental appraisal (significance of -0.4 ), or their interests (significance of -0.7). 


\section{Popularity of Teaching-Learning Methods}

There is no significant difference by parental education in this issue; however, types of settlements cursor some kind. The influence of a particular factor (for example faculty) could be suspected because tendency cannot be detected. Difference by gender is in accordance with the stereotypes: girls prefer creating, while boys tend to rank evaluation and competition highly.

Out of the 15 homework activities offered, the most popular ones reached no more than an average of 3.5, possibly because the general unpopularity of homework among learners (see Table 6). The top one is the collective creation (3.5), while collections, individual creation, heuristic tasks and next-level calculations received 3.2. Typical exercises, for example doing tasks, memorizing poems or content, essay writing and singing, reached an average of 3.0 to 2.8. Not-well-educated parents' children show significant negative difference in activities demanding communicative competences, group work or projects. The same is valid for those learners who live in villages or municipalities.

Table 6

The Popularity of Different Teaching-Learning Methods $(\mathrm{N}=1,236)$

\begin{tabular}{|c|c|c|c|c|}
\hline $\begin{array}{l}\text { Teaching } \\
\text { strategy }\end{array}$ & Item & Mean & St. dev & Way of instruction \\
\hline \multirow{6}{*}{$\begin{array}{l}\text { Constructive } \\
\text { (active learning) }\end{array}$} & Games & 4.68 & .785 & \multirow[b]{2}{*}{$\begin{array}{l}\text { Teacher-learner } \\
\text { cooperation }\end{array}$} \\
\hline & $\begin{array}{l}\text { Discussion, argument, } \\
\text { discourse }\end{array}$ & 4.55 & .873 & \\
\hline & Creation & 4.47 & .922 & \multirow{3}{*}{ Instruction by learner } \\
\hline & Discovery & 4.39 & 1.032 & \\
\hline & Using the internet & 4.38 & 1.152 & \\
\hline & Dramatization & 4.36 & 1.017 & \multirow{3}{*}{$\begin{array}{l}\text { Teacher-learner } \\
\text { cooperation or } \\
\text { instruction by learner }\end{array}$} \\
\hline $\begin{array}{l}\text { Instructive or } \\
\text { constructive }\end{array}$ & Interactive whiteboard & 4.24 & 1.213 & \\
\hline \multirow{5}{*}{ Instructive } & Competition & 4.17 & 1.097 & \\
\hline & Explanation & 4.14 & 1.319 & \multirow{4}{*}{ Instruction by teacher } \\
\hline & $\begin{array}{l}\text { Doing exercises (ordered } \\
\text { by teacher frontally) }\end{array}$ & 3.76 & 1.340 & \\
\hline & Interrogation & 3.25 & 1.385 & \\
\hline & Test-taking & 3.12 & 1.406 & \\
\hline
\end{tabular}

\section{The Correlation between Learning Conditions}

An individual variable had been constructed with factor analysis previously, and active learning methods were also tested with a special highlight on educating selfregulated learning from learners' aspect. As it is displayed in Table 7, among variables, significant correlation was detected except the issue of homework. The result is highly important: learners' personal learning conditions, including learning interesting and useful things (even with the help of non-formal ways, for example, individual research, and faculty), are in strong and significant correlation with self-regulated learning $(\mathrm{r}=0.711$; $\mathrm{p}<0.01$ ). Regression analysis using stepwise model resulted $\mathrm{R}^{2}=0.476$ thus the total effect of the two constructed variables was $47 \%$ on self-regulated learning. The effect of the selfexperienced learning environment was $24 \%$ and $23 \%$ in the case of classroom climate. 
Table 7

The Correlation Matrix of Self-Regulated Learners versus Learners' Learning Conditions

\begin{tabular}{|c|c|c|c|c|c|c|}
\hline & \multirow{2}{*}{$\begin{array}{l}\text { Self-regulated } \\
\text { learner }\end{array}$} & \multicolumn{3}{|c|}{ Learning conditions } & \multicolumn{2}{|c|}{$\begin{array}{l}\text { Active-learning } \\
\text { methods }\end{array}$} \\
\hline & & Objective & $\begin{array}{l}\text { Classroom } \\
\text { climate }\end{array}$ & $\begin{array}{c}\text { Self- } \\
\text { experienced }\end{array}$ & $\begin{array}{c}\text { At } \\
\text { school }\end{array}$ & $\begin{array}{c}\text { At } \\
\text { home }\end{array}$ \\
\hline Self-Regulated Learner ${ }^{1}$ & 1 & & & & & \\
\hline Objective $^{2}$ & $.218^{* * *}$ & 1 & & & & \\
\hline Classroom Climate $^{3}$ & $294^{* * *}$ & $.552^{* * *}$ & 1 & & & \\
\hline Self-Experienced ${ }^{4}$ & $.711^{* * *}$ & $.349^{* * *}$ & $.516^{* * *}$ & 1 & & \\
\hline ALM at school ${ }^{5}$ & $.063^{*}$ & $.077^{* *}$ & $.113^{* *}$ & $.144^{* * *}$ & 1 & \\
\hline ALM at home $^{6}$ & $.207^{*}$ & .108 & .274 & $.447^{* *}$ & .187 & 1 \\
\hline
\end{tabular}

$\mathrm{N}=1,225$

Double asterisks indicate that correlation is significant at the 0.01 level (2-tailed).

Single asterisk indicates that correlation is significant at the 0.005 level (2-tailed).

Detailed explanation of the factors:

1. A self-regulated learner who is able to plan their learning and is motivated without markbased evaluation is a so-called "entrepreneur".

2. The objective and tangible environment of learning.

3. The psychological climate of the classroom.

4. Learning interesting and useful things, extra learning possibilities are available.

5. Non-formal individual learning at school, having enough time for it.

6. Type of homework.

The abovementioned results of the nation-wide survey suggest that learners do not have positive experience in connection with individual learning and cooperation, because they are used to frontal work (see Table 5); nevertheless they (would) prefer active learning methods in out of class learning, according to the preference survey on learning activities (see Table 6). It could be supported by the result that there are Grade 4 students who dislike attending school, albeit they appreciate their schools and teachers (see Table 4).

\section{Challenge-Based Learning in UKids Thematic Projects}

In its holistic-approached learning management system, UKids applies 18 different challenges which are distributed into three categories according to the TRIO model (Teufel, 2019). Six relevant challenges are presented and discussed in details below.

\section{The Scope and Role of the Project}

A significant feature of the UKids project is the collective learning by learners from Grades 3 to 5 in various situations: in formal and informal ways, by directions or freely, together or individually. With the help of school principals and teachers, the universitylecturer leaders, operating as facilitators of the programme, support the teacher candidates' researcher, developer and actuator work on the basis of challenges and doing-by-learning teaching-learning strategies.

As a result of this, teacher candidates' participation means an intensive self-regulated learning: they familiarize with foreign-language bibliography of the project, observe 
and get acquainted with the target groups; they plan ahead with the teachers and professionals; then they schedule, perform, document and analyse. Seven teacher candidates have written excellent theses about their researches so far, one of them won the second prize on a national researcher competition for university students, while two papers for a similar competition are in progress. The expeditious nature of the project for the tertiary education is definite.

\section{Key Properties of the Already-Implemented Thematic Challenges}

In the spring of 2018, one class was involved with the intention of adapting the Trash Value Challenge and developing a diagnostic questionnaire to test the pilot. By a fortunate chance, in a Grade-4 class with 26 learners the subject Nature was taught by teacher trainer Ildikó Józsa, who had been putting a strong emphasis on educating sustainability and skills for entrepreneurship with active learning methods since Grade 1 . This made it possible to prioritize her class and use the other classes involved as control groups. No drawbacks were present because of learners' similarity in the classes. Learning was based on challenge-based project work in which learners had the possibility of choosing subtopics having the highest interest and motivation for learning and acquainting.

The Trash Value Challenge was more than a pilot project, since it was repeated and joined with another project for a whole grade. The ELTE Gyertyánffy István Practicing Primary School had had a long tradition focusing on projects that lead to sustainable and environmental-friendly behaviour; nevertheless, it was the first time that there has been a conscious focus on the element of children's entrepreneurial skills. Another new feature of this project was that besides the learners, their parents and practicing teacher candidates took part (Józsa, 2019). The Grade-4 learners started the challenge by filling a planner booklet in which they were guided by a little mouse, Levi. In this document, they could sort out their preliminary knowledge and new ideas related to the topic. After that, they created usable objects by finding and recycling materials that had been intended to be thrown away. Finally, they showcased their designs and products in groups, evaluated their own presentations, their process of learning, and the future benefits of their freshly-gained knowledge (Angyal, 2018).

The extraordinary thematic project titled Market-Day Challenge was based on the results of the Trash Value Challenge and the educational programme of the Community Challenge. Almost 100 learners and teacher candidates took part in the programme (UKids, 2018). Fourth graders manufactured and sold goods made from trash to their parents and classmates at the fair for Lucia Day, and donated their income to an animal shelter. The process of scheduling, organizing and production was planned with their planner booklet and log. The project made them practice social skills. It taught about social responsibility, the importance of ideas, and the market and marketing (the system of demand and supply, the marketability of goods and pricing).

Similarly to the before-mentioned challenge, Extreme ("Body-waking") Challenge was tried out in one class as a part of the out-of-classroom activities (Szaszala, 2020). The peculiarity of this project is the family-based cooperation, and it invites learners to do sport activities out of their schools and beyond school-time. Learners' continuous participation was supported with the challenge booklet featuring a mouse pursuing sports. Learners had the possibility of choosing by the gender of the mouse and colour 
them. Learners' favourite sports, their sporting habits and activities done during the summer were noted in the logs, and then the filled booklets and gained experiences were shared in September.

The goal of the Empathy ("Africa") Challenge was to create a ready-to-teach sensitization programme related to Africa in order to develop social competencies, strengthen learners' pro-social behaviour, educate for tolerance and acceptance, and form their outlook (Márföldi, 2020). The project was framed by a teacher candidate who considered the fact that humans do not form an isolated, culturally homogenous community; thus peaceful coexistence and effective labour require the acquisition of mutual respect and acceptance. Honouring diversity, developing social competencies, and educating for active and responsible citizenship, must be present in contemporary education in the context of emerging multicultural and multilingual society. The results of the implemented project proved that active and project-oriented learning was able to teach universal human values since learners tried to find real answers to real social challenges while they were disputing global problems, attributes, prejudices, and the difference between reality and media-suggested images.

Another challenge was titled Be A Yes: Concentrate On The Things Which Are Good For You! Besides the social entrepreneurship, it put an emphasis on self-image, self-knowledge, and reflective skills. During the activities, self-improvement and establishing self-knowledge, developing self and peer-reflexion, and cooperation were highlighted; however, many areas of competence were covered. In other words, this challenge included teaching learning, forming environmental-conscious thinking, social competencies, expression, mathematical skills, movement training, handcraft, artistic skills, critical thinking and digital competency. The lessons consisted of playful activities for individual, pair and group work, and matched to Gardner's theory of multiple intelligences (Gardner, 1983). Learners could try out drawing, writing, oral, kinaesthetic and musical activities (Kuhár, Bognár, \& Hercz, 2019).

Extraordinary circumstances, children with special needs. One setting of the challenge $B e$ A Yes was a temporary children's home where children are welcomed for a month or for a year until an institution or fosterers are found for them. Those who are educated like this are severely deprived, brought up under harsh social conditions. Typically, their parents are undereducated and often unemployed, or have housing issues, while deviant behaviour could be regular in their family, too. The designerteacher candidate of the project set out with the aim of giving a chance to these children to succeed in life and to follow an example accepted by their society through the development of social skills. The author used the material of the Youth Start Empathy Challenge and Mindfulness projects (Youth Start, 2018) to plan the series of lessons (Ferkel, 2020).

The adaptation and implication of different projects, for example "Trash Value" or "Be A Yes", did not just develop learners' social entrepreneurial skill (Angyal \& Hercz, 2019) but contributes to their growth in order to become independent and innovative individuals and self-regulated learners. Side effects related to the project must also be considered since it is reasonable to assume that it has effects on teacher candidates involved into its execution, and a similar phenomenon could occur in the case of learners who could actuate their parents and other adults. 


\section{The Effects of the Challenges on Learners}

In the second and third phases of the research (see Table 2), before the initiation of the UKids programme, learners' views were mapped in order to be thoroughly enlightened upon their self-efficacy, competencies required for entrepreneurial life, and their opinion about educational circumstances. The results of that survey have already been published by Angyal and Hercz (2018). Now our intention is to emphasize that, of classes consisting of children with nearly similar socioeconomic status, one shows a higher level of selfefficacy in which experienced four-year-long environmental-conscious teaching-learning methods apply active learning and parental inclusiveness (for the results of the independent Samples t-test see Table 8). It is reasonable to assume that the elements of the nonconsciously-used challenge-based learning had major effects on the participants. This supports the necessity for involving more learners into UKids programme.

Table 8

The Self-Efficacy of the Classes (Using a Contracted Variable of Eight Features)

\begin{tabular}{lcccc}
\hline & $\mathrm{N}$ & Mean & Std. deviation & Std. error mean \\
\hline Classes ahead the project & 111 & 3.56 & .601 & .057 \\
\hline Pilot class & 24 & 3.94 & .324 & .066 \\
\hline
\end{tabular}

Sig: $\mathrm{p}<0.05$; Diff. means: 0.7 .

\section{Teacher Candidates' Reflections on Challenge-Based Projects}

The primary school teacher candidates who participated in the UKids project used a combination of research methods to realize each project, including the proper development of learners' planner booklets. For learners, that document served as guidance for planning and executing challenges, and to give feedback and self-reflection. One of the teacher candidates' tasks was to analyse the booklets in order to present project reports which were later elaborated to serve as BA-degree theses in many cases. In this study we desk-researched those theses to investigate what positive and negative features were articulated by the learners in their planner booklets.

The qualitative data software arranged seven thematic groups which are introduced in Table 9 in decreasing order by frequency. Dichotomy is present: not just antonymic expressions occur in classes but some learners reject childhood-related items because of childishness (for example tales as frameworks or symbols); nevertheless, those are highly preferred by others. 
Table 9

The Dimensions of Age-Group-Related Dichotomy Based on the Interviews with Lower Primary Teachers, Teacher Candidates' Observations; Learners' Planner Booklets and their Feedbacks

\begin{tabular}{|c|c|c|c|}
\hline & $\begin{array}{l}\text { Middle-childhood } \\
\text { (still attractive) }\end{array}$ & Some examples & $\begin{array}{c}\text { Preadolescence } \\
\text { (already attractive) }\end{array}$ \\
\hline 1. & $\begin{array}{c}\text { dominancy of } \\
\text { self-interest }\end{array}$ & $\begin{array}{l}4 \text { being in the centre; learning about } \\
\text { themselves; do not like give things for } \\
\text { others } \\
\text { enjoy to create things or collect } \\
\text { donation for others; enjoy to manage } \\
\text { programs for others; enjoy the } \\
\text { "secret-role" as helpers }\end{array}$ & $\begin{array}{c}\text { attracted to heroic } \\
\text { roles }\end{array}$ \\
\hline 2. & own environment & $\begin{array}{r}4 \text { create things for their family or school } \\
\text { learning about economic problems } \\
\text { sustainability; social problems; } \\
\text { global problems }\end{array}$ & $\begin{array}{l}\text { things of } \\
\text { the world }\end{array}$ \\
\hline 3. & self-oriented & $\begin{array}{l}4 \text { enjoyed to use and adapt planner } \\
\text { booklets for themselves } \\
\text { inviting and teaching other children; } \\
\text { collect donations for poor children; } \\
\text { joyful cooperation }\end{array}$ & $\begin{array}{c}\text { curious about } \\
\text { others }\end{array}$ \\
\hline 4. & $\begin{array}{l}\text { world of tales } \\
\text { and games }\end{array}$ & $\begin{array}{l}\text { enjoy using fairy-tale heroes } \\
\text { (Superhero Mouse); colouring and use } \\
\text { Levi Mouse; play drama based on } \\
\text { a fairy-tale story } \\
\quad \text { make sg against global problems }\end{array}$ & $\begin{array}{l}\text { real events and } \\
\text { happenings, } \\
\text { the world of } \\
\quad \text { adults }\end{array}$ \\
\hline 5. & $\begin{array}{l}\text { governable: teacher } \\
\text { and adult-commanded }\end{array}$ & $\begin{array}{ll}4 \text { parental involvement } \\
\text { volunteer work }\end{array}$ & $\begin{array}{c}\text { self and } \\
\text { peer-commanded }\end{array}$ \\
\hline 6. & copying & $\begin{array}{l}\text { closed activities; suggested products for } \\
\text { sale } \\
\text { open-ended activities, billboards }\end{array}$ & $\begin{array}{l}\text { creating and } \\
\text { innovation }\end{array}$ \\
\hline 7. & safety & $\begin{array}{l}\text { wanted adults tell the best idea, best } \\
\text { product for selling } \\
\text { find and create things to sell; } \\
\text { organise market }\end{array}$ & risk-taking \\
\hline
\end{tabular}

Although there is an age-related dichotomy, it stood out that the temporary period that learners experience already triggers the demand for self-directed learning and civic thinking, and these concepts are presented as positive values in the self-reflective chapter of learners' planner logs. The executed projects contained the peculiarities of challengebased learning (cfr. Table 1); and the educational and personal-developmental effects of the challenges fulfilled the competency categories listed in theoretical works. The following quotation illustrates the abovementioned findings comprehensively:

"Through the joy of creative design, the children deepened their knowledge of global problems such as pollution, climate catastrophes, sustainability, waste treatment and their social sensitivity; communication skills and social connections had developed. The last question of the planner booklet was this: If you could teach three things to someone from this challenge, what would those be? The most important answers were the following: 
The saving of the planet is most important! It's easier working together, than alone! Don't be afraid of the task once you started it, it will be easy!” (Józsa, 2019).

\section{Conclusions}

The present study examined the hitherto Hungarian adaptation and implementation of the Erasmus UKids programme in the context of supporting life-long learning and sustainability. Based on these theoretical works, it was assumed that $21^{\text {st }}$ century education must provide teaching-learning for a new generation of children who require a different teaching-learning approach. This is because of their different scope of interests, as they live in a different environment and must develop skills and competences needed in the already-globalised world. One option could be the problem-based and challenge-based learning introduced.

Latter-mentioned was the basis for the UKids programme; its investigation occurred in four phases with the help of mixed research methodology, including surveys and document analysis. The comprehensive nature of the research was supported by the multi-role execution of the programme. The key questions of the research concerned learners' attitude towards school and learning, and the possible impacts and age-dependency of the implied programme.

The quantitative research sections confirmed that although the general liking of school is 3.7, unambiguously, one third of respondents do not like attending school. At their age, learners' relationships with their teachers is outstanding: levels 4 and 5 occurred in $93 \%$ of the answers. With some critics, there is a lower satisfaction with learners' objective learning circumstances, but dissatisfaction with high deviation is also present in the case of non-formal learning possibilities. The attitude towards learning is not influenced by the size of respondents' domestic domain; however, highly-qualified parents' children are more critical of their learning circumstances (see Table 4). The hypothesis for the preference of non-traditional learning forms is not supported: learners, who are used to frontal or frontally-directed pair-work, have not had the possibility of experiencing individual and communal creativity; therefore they prefer traditional work forms (Claxtron, 2013). As for active learning, which is in strong relationship with challengebased learning, it turned out that learners prefer constructive learning strategies, learnercommanded and teacher-learner-cooperation-based methods (see Table 6). Although the respondents are from Generation Z, the stereotypical devotion to information and communication technologies is not proven to be true (Francis \& Hoefel, 2018); digital devices are still important but umpteenth on their list of preference.

In the qualitative phase, the desk-research of the primary school teacher candidates' theses on participating learners' planner booklets and other documents suggests that the entrepreneurship education by the UKids programme complies to its TRIO model (Lindner, 2018) and it exclusively uses challenge-based learning. Participants' entrepreneurial and other skills and competences have been developed, the narratives of the self-assessment section of their planner booklets contained the elements of challengebased learning without being influenced by their teachers. The learners are in transition: they are still children and already preadolescents; this dichotomy was verified by document analysis (see Table 9). Nevertheless, the framework of the UKids programme is proven to be suitable for handling the challenge of age-related liminality. 
Overall, the authors of this present paper are convinced that the practical implication of the UKids programme realises its theoretical framework to the full, and the challengebased learning is an upstanding possibility for eight-to-eleven-year-old children to become life-long learners.

\section{References}

Angyal, S. (2018). Hétköznapi hôsök nevelése: vállalkozóképesség fejlesztésének lehetôsége gyermekkorban [Educating ordinary heroes: An opportunity to develop entrepreneurship in childhood]. Manuscript, Hungary: Országos Diákköri Konferencia.

Angyal, S., \& Hercz, M. (2019). Hétköznapi hôsök nevelése: vállalkozóképesség fejlesztésének lehetôsége gyermekkorban [Educating ordinary heroes: An opportunity to develop entrepreneurship in childhood]. In Vitályos, G. (Ed.), Mester és tanítvány [Master and disciple] (pp. 10-16). Budapest: Eötvös Loránd University, Faculty of Education.

Apple, Inc. (2008). Apple classrooms of tomorrow - Today learning in the $21^{\text {st }}$ century. Cupertino, California: Apple Inc.

Bandura, A. (1986). Social foundations of thought and action: A social cognitive theory. Englewood Cliffs, NJ: Prentice-Hall.

Bronfenbrenner, U. (1979). The ecology of human development. Cambridge, MA: Harvard University Press.

Bruner, J. S. (1996). The culture of education. Cambridge, MA: Harvard University.

Boud, D., \& Feletti, G. I. (Eds.). (1997). The challenge of problem-based learning (2nd ed.). London: Kogan Page Limited.

Bowen, G. A. (2009). Document analysis as a qualitative research method. Qualitative Research Journal, 9(2), 27-40. doi: 10.3316/QRJ0902027

Corbin, J., \& Strauss, A. (2011). The basics of qualitative research. Thousand Oaks: Sage Publications Inc.

Claxtron, G. (2013). What is the point of school? Rediscovering the Heart of Education. New York: Oneworld Publications.

Claxtron, G. (2017). Learning power, teaching attitude. TEDxNorrkopingED. Retrieved from https://www.youtube.com/watch? $v=J x W y b v n s 1 j g \& t=56 \mathrm{~s}$

Csapó, B. (2012). Goals of learning and the organization of knowledge. In Leutner, K. E., \& Kenk, D. M. (Eds.), Kompetenzmodellierung. Zwischenbilanz des DFG-Schwerpunktprogramms und Perspektiven des Forschungsansatzes [Competency modeling. Interim balance of the DFG priority program and perspectives of the research approach] (pp. 12-27). Weinheim. Basel: Beltz, Zeitschrift für Pädagogik, Beiheft.

Creswell, J. W. (2009). Research design qualitative, quantitative and mixed methods approaches. Thousand Oaks: Sage Publications.

Erikson, E. H. (1963). Childhood and society (2 $2^{\text {nd }}$ ed.). New York: W. W. Norton.

Fedosejeva, J., Boče, A., Romanova, M., Iliško, Dz., \& Ivanova, O. (2018). Education for sustainable development: The choice of pedagogical approaches and methods for the implementation of pedagogical tasks in the anthropocene age. Journal of Teacher Education for Sustainability, 20(1), 157-179. 
Feldman, D. H. (1999). A developmental evolutionary perspective on gifts and talents. Journal for the Education of the Gifted, 22(2), 159-167.

Ferkel, K. M. (2020). Hétköznapi hôsök nevelése: szociális kompetenciafejlesztés gyermekotthonban [Learning educating ordinary heroes: Developing social competence in an orphanage]. Thesis manuscript, ELTE TÓK. Budapest: ELTE TÓK.

Francis, T., \& Hoefel, F. (2018). 'True Gen': Generation Z and its implications for companies. The influence of Gen $Z$ - the first generation of true digital natives $-i s$ expanding. McKinsey \& Company.

Fülöp, M. (2019). Teaching citizenship in Hungary. In Davies, I., Evans, M., Fülöp, M., Kiwan, D., Peterson, A., \& Sim, J. B.-Y. (Eds.), Taking action for change: Educating for youth civic engagement and activism (pp. 44-51). York: University of York.

Gardner, H. (1983). Frames of mind: The theory of multiple intelligences. New York City: Basic Books.

Gliner, J. A., Morgan, G. A., \& Leech, N. L. (2017). Research methods in applied settings. An integrated approach to design and analysis. New York, NY: Routledge.

Heasly, B., Lindner, J., Iliško, Dz., \& Salīte, I. (2019). Editorial. Discourse and Communication for Sustainable Education, 10(2), 1-4.

Heasly, B., Lindner, J., Iliško, Dz., \& Salìte, I. (2020). From initiatives, to insights, to implementation of the sustainability and securitability agenda for 2030. Discourse and Communication for Sustainable Education, 11(1), 1-4.

Hercz, M. (2019). YouKids - social entrepreneurship programme for kids. In Davies, I., Evans, M., Fülöp, M., Kiwan, D., Peterson, A., \& Sim, J. B.Y. (Eds.), Taking action for change: Educating for youth civic engagement and activism (pp. 47-48). York: University of York.

Igel, C., \& Urquhart, V. (2012). Generation Z, meet cooperative learning. Middle School Journal, 43(4), 16-21. doi: 10.1080/00940771.2012.11461816

Johnson, L. F., Smith, R. S., Smythe, J. T., \& Varon, R. K. (2009). Challenge-based learning: An approach for our time. Austin, Texas: The New Media Consortium.

Johnson, D. W., \& Johnson, R. T. (1999). Making cooperative learning work. Theory into Practice, 38(2), 67-73.

Józsa, I. (2019). Trash value challenge. Retrieved from https://ukidsplatform.eu/Trash ValueChallenges/TrashChallengeHungary/tabid/1196/Default.aspx

Kuhár, A., Bodnár, G., \& Hercz, M. (2020). Be a Yes. Strengths treasure hunt. Presentation at Entrepreneurship with Citizenship Conference, January 20 ${ }^{\text {th }}, 2020$. School of Education of Polytechnic of Porto, Porto.

Lindner, J. (2019). Entrepreneurial spirit for the whole school - ways to become an e.e.si-Entrepreneurship School. Discourse and Communication for Sustainable Education, 10(2), 5-12.

McAdams, D. P., \& Palsh, J. L., (2006). A new big five: Fundamental principles for an integrative science of personality. American Psychology, 61, 204-217.

Márföldi, N. (2020). Az érzékenyítés szociális kompetencia fejlesztésében rejlőlehetôségeinek vizsgálata [Investigating the potential of sensitization in the development of social competence]. Thesis manuscript. Budapest: ELTE TÓK.

Nichols, M., Cator, K., \& Torres, M. (2016). Challenge based learner user guide. Redwood City, CA: Digital Promise.

Piaget, J. (1983). Piaget's theory. In Mussen, P. H. (Ed.), Handbook of child psychology, $4^{\text {th }}$ Ed., 1, History, theory and methods. New York: Wiley. 
Sahin, M., Akbasli, S., \& Yelken, T. Y. (2010). Key competences for lifelong learning: The case of prospective teachers. Educational Research and Reviews, 5(10), 545556.

Salīte, I., Mičule, I., Kravale, M., Iliško, Dz., \& Stakle, A. (2007). Toward the sustainability in teacher education: Promise of action research. In Pipere, A. (Ed.), Education and sustainable development: First steps toward changes (pp. 263-292), 2. DU: Saule.

Samuelsson, I. P., \& Kaga, Y. (Eds.). (2008). The contribution of early childhood education to a sustainable society. Paris: UNESCO.

Slušnienè, G. (2019). Possibilities for development of emotional intelligence in childhood in the context of sustainable education. Discourse and Communication for Sustainable Education, 10(1), 133-145.

Szaszala, E. (2020). Testébresztő. A mozgás iránti attitüd fejlesztése szabadidős egyéni kihívásokra építve [Developing an attitude to movement based on leisure individual challenges]. Thesis manuscript. Budapest: ELTE TÓK.

Takács, N. (2019). Views of primary school and kindergarten teacher students about lifelong learning. Raziskovanje v vzgoji in izobrazevanju [Research in education]. Ljubljana: Institute of Pedagogy, 67-81.

Teufel, I. (2019). Holistic learning. Entrepreneur. Wien: IFTE.

Trilling, B., \& Fadel, C. (2009). 21 $1^{\text {st }}$ century skills: Learning for life in our times. John Wiley \& Sons.

UKids (2018). Project webpage. Retrieved from https://ukidsplatform.eu/

UNESCO (2014). Roadmap for implementing the Global Action Programme on Education for Sustainable Development. Paris: UNESCO.

Ülavere, P. (2017). Value education in Estonian preschool child care institutions. Journal of Teacher Education for Sustainability, 19(1), 129-146.

Vygotsky, L. (1962). Thinking and speaking. Cambridge: The M.I.T. Press.

Walker, A., Leary, H., Hmelo-Silver, C., \& Etmer, P. A. (Eds.). (2015). Essential readings in problem-based learning. West Lafayette: Purdue University Press.

WEF (World Economic Forum). (2016). New vision for education: Fostering social and emotional learning through technology. Geneva, Switzerland: World Economic Forum.

Correspondence regarding this article should be addressed to Mária Hercz. Email: hercz.maria@gmail.com 